\title{
THE LICHEN GENUS CHIODECTON IN TASMANIA
}

\author{
by G. Kantvilas and G. Thor
}

(with one text-figure and one plate)

Kantvilas, G. \& Thor, G. , 1993 (31:viii): The lichen genus Chiodecton in Tasmania. Pap. Proc. R. Soc. Tasm. 127:39-41.

https://doi.org/10.26749/rstpp.127.39 ISSN 0080-4703.Tasmanian Herbarium, GPO Box 252C, Hobart, Tasmania 7001

(GK); Department of Botany, Stockholm University, S-106 91 Stockholm, Sweden (GT).

Three species of Chiodectonoccur in Tasmania: C. colensoi, the endemic C. flavovirens, and C. montanum which is reported here from Australia for the first time. It was known previously from two localities in New Zealand. A key to these three Tasmanian species is provided, together with notes on their ecology and distribution.

Key Words: lichens, Tasmania, Chiodecton.

\section{INTRODUCTION}

Chiodecton is a crustose genus in the lichen family Opegraphaceae, characterised by ascocarps aggregated into thalline, stroma-like structures, anticlinallyarranged, sparsely branchedexcipulum hyphae, sparsely branched paraphysoids, and by thin-walled, fusiform, usually three-septate ascospores. The thallus typically has an orange-pink tinge when fresh (due to the presence of the alga Trentepohlia) and the thalline stromata are convex, rounded or irregularly elongate, and mostly to $2 \mathrm{~mm}$ wide. The minute apothecial discs, c. $0.1 \mathrm{~mm}$ diam., are visible as numerous black dots or short lines on the surface of the stroma. The epithecium and hypothecium are typically dark brown, turning dull olivegrey in $\mathrm{KOH}$. Most species are superficially similar in gross morphology (pl. 1) and differ chiefly by anatomical characters.

The genus is primarily tropical-subtropical in distribution, although $C$. colensoi extends into temperate areas and C. montanum and $C$. flavovirens are confined there. Most species of Chiodecton are corticolous in moist, sheltered habitats and only $C$. montanum is strictly saxicolous. However, four other species, C. colensoi, C. congestulum, C. leptosporum and C. malmei, occasionally occur on rocks (Thor 1990).

Kantvilas (1989) recorded only one species of Chiodecton from Tasmania, C. colensoi (Massal.) Müll. Arg., a widely distributed lichen in eastern Australia and New Zealand. In a revision of the genus, Thor (1990) described a further species, C. flavovirens Thor which is apparently endemic to Tasmania. Recently one of the authors (GK) collected a third species from Tasmania, C. montanum Thor, previously known only from New Zealand.

\section{KEY TO CHIODECTON IN TASMANIA}

1. Hymenium inspersed with oil droplets and granules.. 2 Hymenium lacking oil droplets or granules.. C. colensoi

2. Thallus saxicolous; lower part of the medulla with yellow pigments, mainly in the stroma-like ascocarps C. montanum

Thallus corticolous, lignicolous or occurring on dead leaves; lower part of the medulla lacking yellow pigments

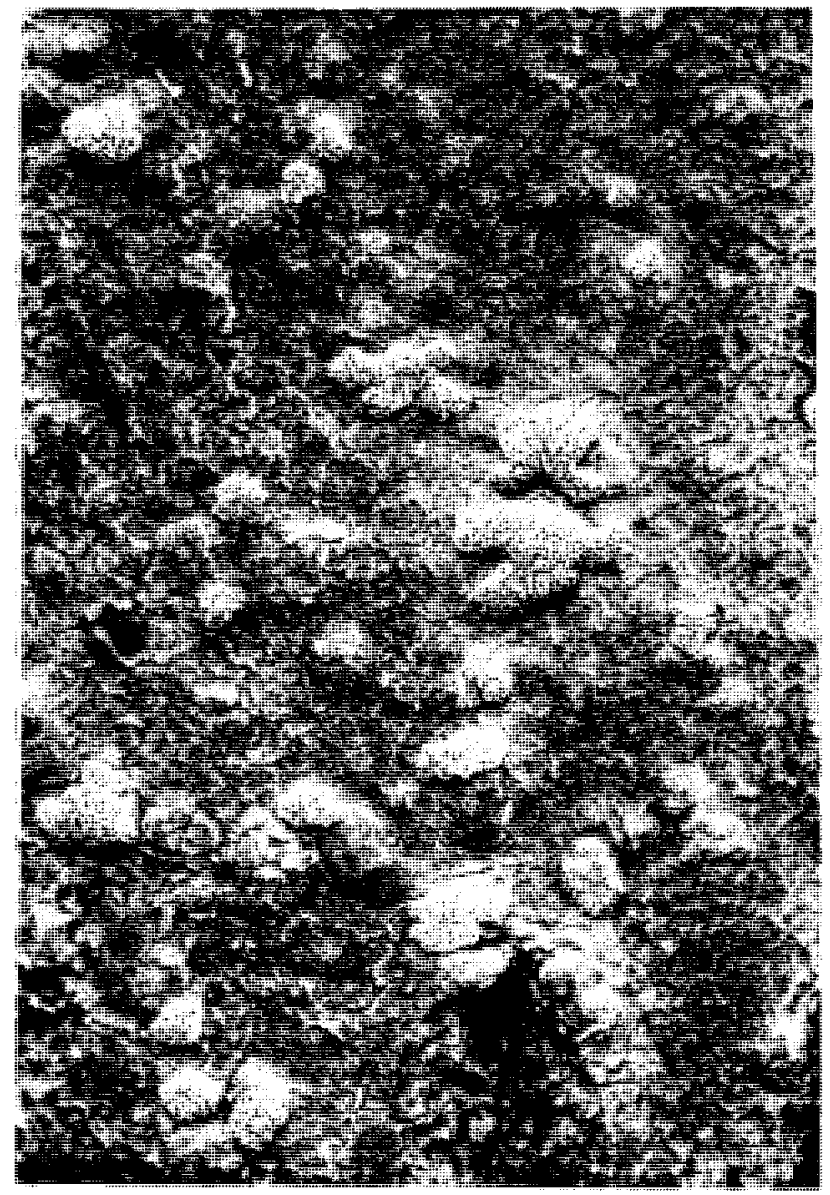

PLATE 1

Chiodecton colensoi, showing typical wart-like thalline stromata with minute blackish apothecial discs, visible as black dots and lines on the surface of each stroma (photo Bruce Fubrer). 


\section{THE SPECIES}

\section{Chiodecton colensoi (Massal.) Müll. Arg. Bull. Herb. Boissier 2: App. 1: 86 (1894)}

A full description and discussion of the morphology, anatomy and distribution of this species are given by Galloway (1985) and Thor (1990). For photographsee plate 1. It is characterised chiefly by the absence of abundant oil droplets in the hymenium. Chiodecton colensoi is the most common Tasmanian species of the genus (fig. 1), being widespread in a wide range of cool temperate rainforest vegetation as well as occurring in some wet sclerophyll forests. It occurs exclusively on smooth bark, usually in shaded, moist microhabitats, and typical host trees include Atherosperma, Anodopetalum, young Nothofagus cunninghamii and Tasmannia. In rainforest, common lichens associated with Chiodecton colensoiinclude Phaeographis exaltata, Megalospora lopadioides, Parmeliella nigrocincta, Phlyctis subuncinata, Thelotrema lepadinum, Opegrapha stellata and Coccotrema cucurbitula. The record from Tasmania of Chiodecton perplexum $\mathrm{Nyl}$. byShirley (1894) refers to C. colensoi (Kantvilas 1988).

Selected specimens examined: Australia, Tasmania: Mount Arthur, 1885-95, F.R.M. Wilson 1115 (G, COLO). Weldborough, $41^{\circ} 12^{\prime} \mathrm{S}, 147^{\circ} 54^{\prime} \mathrm{E}$, on Atherosperma moschatum in rainforest, $770 \mathrm{~m}$ a.s.l., 1981, Kantvilas 1135/81 (HO, BM). Arthur River, on Nothofagus cunninghamii in rainforest, $270 \mathrm{~m}$ a.s.l., 1982, Kantvilas 65/82 (HO, BM). Mt Dundas track, 41 ${ }^{\circ} 55^{\prime} \mathrm{S}, 145^{\circ} 28^{\prime} \mathrm{E}$, on Anodopetalum biglandulosum in rainforest, $670 \mathrm{~m}$ a.s.l., 1988, Kantvilas 541/88 (HO). Balts Spur, Tasman

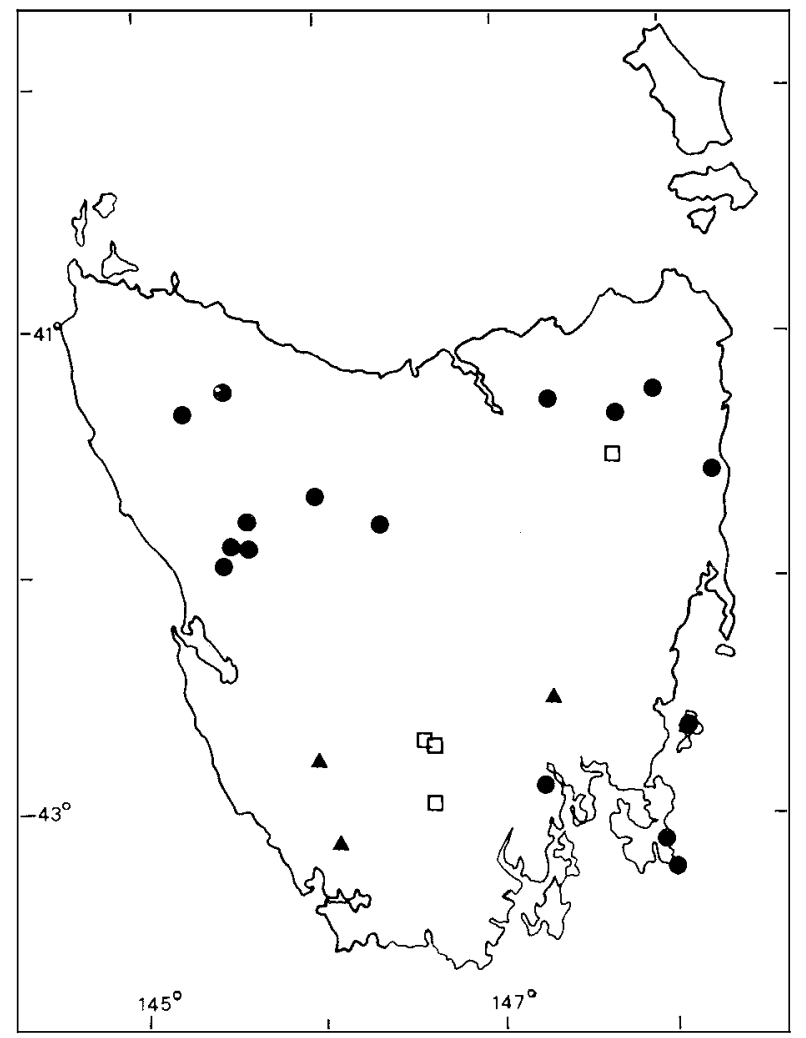

FIG. 1 - Distribution of Chiodecton in Tasmania: C. colensoi (O); C. flavovirens (a); C. montanum (A)
Peninsula, $43^{\circ} 05^{\prime} \mathrm{S}, 147^{\circ} 56^{\prime} \mathrm{E}$, on canopy twigs of Nothofagus cunninghamii, $420 \mathrm{~m}$ a.s.l., 1983, Kantvilas 157/83 (HO). Murchison Highway at saddle over Mt Black, 41 47'S, $145^{\circ} 35^{\prime} \mathrm{E}$, on Anodopetalum biglandulosum in rainforest, $530 \mathrm{~m}$ a.s.l., 1989, Kantvilas 269/89 (HO). Track to The Blade, Cape Pillar, $43^{\circ} 14^{\prime}$ S, $148^{\circ} 00^{\prime}$ E, 1973, M. Kershaw s.n. (HO). Anthony Road near Lake Sandra Track, $41^{\circ} 50^{\prime} \mathrm{S}$, $145^{\circ} 36^{\prime} \mathrm{E}$, on Anodopetalum biglandulosum in rainforest, 580 m a.s.l., 1989, Kantvilas 31/89 (HO). Little Fisher River, $41^{\circ} 45^{\prime} \mathrm{S}, 146^{\circ} 20^{\prime} \mathrm{E}$, on Atherosperma moschatum in rainforest, $820 \mathrm{~m}$ a.s.l., 1984, Kantvilas 705/84 (HO, BM). Mount Wellington, alt. $600 \mathrm{~m}$ [2000 feet], 1891, W.A. Weymouth 118 (VT). St Marys Pass, 1891, F.R.M. Wilson s.n. (G).

\section{Chiodecton flavovirens Thor, Opera Botanica 103: 41 (1990)}

See Thor (1990) for a full description and photograph. Chiodecton flavovirens is an uncommon Tasmanian endemic lichen from wet forests. Superficially similar to C. colensoi, it is characterised by the presence of oil droplets and granules in the hymenium, and by its unique ecology. It is known from highland areas where it grows in locally dry microhabitats such as on the papery, fibrous bark of Leptospermum lanigerum and on the dead leaves of Richea pandanifolia (Thor 1990). The latter habitat tends to be particularly rich in lichens with typical species including Lecanactis abietina, and species of Chaenotheca, Cliostomum and Opegrapha.

Additional specimen examined (see also Thor 1990): Australia: Tasmania: Track to Nevada Peak, $42^{\circ} 54^{\prime}$ S, $146^{\circ}$ $41^{\prime} \mathrm{E}$, on dead dry leaves of Richea pandanifolia in rainforest, 800 m a.s.l., 1993, Kantvilas 19/93 (HO, S).

\section{Chiodecton montanum Thor., Opera Botanica 103: 52 (1990)}

A full morphological description and photograph are provided by Thor (1990). Chiodecton montanum is characterised by the presence of yellow pigments (secalonic acid derivatives and skyrin) in the medulla, a thallus closely attached to the substrate, and an hymenium inspersed with oil droplets and granules. The species is most closely related to $C$. flavovirens (see key above) from which it is distinguished by the additional characters of a darker thallus colour and the presence of a prothallus (sometimes almost lacking).

In collections of $C$. montanum from Tasmania, only small amounts of the yellow pigments are present in the medulla surrounding the ascocarp. Hence these are detected best in microscope preparations where the pigments turn red and dissolve in $\mathrm{KOH}$. Tasmanian material also differs from.New Zealand material by the slightly shorter ascospores: material from Tasmania - (41-) 43-50 (-56) $\times$ (3-) 3-4 (-4) $\mu \mathrm{m}$ (length: $\mathrm{X}=46.5 \mu \mathrm{m}, \mathrm{SD}=3.1 \mu \mathrm{m}, \mathrm{n}=$ 120 ; width: $\mathrm{X}=3.2 \mu \mathrm{m}, \mathrm{SD}=0.4 \mu \mathrm{m}, \mathrm{n}=120)$; material from New Zealand - (44-) 47-53(-57) × (3-) $3(-4) \mu \mathrm{m}$ (length: $\mathrm{X}=50.0 \mu \mathrm{m}, \mathrm{SD}=3.0 \mu \mathrm{m}, \mathrm{n}=60$; width: $\mathrm{X}=$ $3.1 \mu \mathrm{m}, \mathrm{SD}=0.2 \mu \mathrm{m}, \mathrm{n}=60)$. Material of $C$. colenso $i$ from Australia has similarly slightly shorter spores than the material from New Zealand (Thor 1990). 
Distribution and habitat

Chiodecton montanum was known previously from only two localities in New Zealand, one in the North Island $(1000 \mathrm{~m}$ a.s.l.) and one in the South Island (1080 $\mathrm{m}$ a.s.l.) (Thor 1990). In Tasmania, C. montanum is known from three localities (fig.1). Two are from Precambrian metamorphic peaks in the remote southwestern area, where the species was associated with normally corticolous species such as Megalospora lopadioides and species of Sphaerophorus. This region is characterised by a high rainfall (up to c. $3000 \mathrm{~mm}$ per annum) and supports a highly interesting lichen flora, rich in endemic species or taxa with a restricted distribution, especially from genera of Gondwanan origin, e.g. Siphula (Kantvilas et al. 1992, Kantvilas \& Jarman 1991). The third locality is from dolerite rocks in southeastern Tasmania, where C. montanum was associated with Rinodina murrayi and species of the Parmeliaceae. This is a most remarkable ecological disjunction, in that this locality is in a markedly drier (annual rainfall c. $700 \mathrm{~mm}$ ), milder macroclimate and, with the apparent notable exception of Chiodecton montanum, shares very few cryptogam or phanerogam species with the southwestern mountains. At all three localities, Chiodecton montanum occurs in moist, very sheltered rock crevices.

Chiodecton montanum is a further example of a southern Australian/Tasmanian-New Zealand disjunction. Biogeographic connections between these regions are well known and have been discussed by many authors (e.g. Galloway 1990). Similar distributions have been found in, for example, species of Megalospora (Sipman 1983), Sphaerophorus (Tibell 1987) and, most recently, Roccellina (Tehler et al. 1991).

Specimens examined: Australia, Tasmania: Mt Sprent, on sheltered overhangs amongst alpine quartzite boulders, $42^{\circ} 48^{\prime} \mathrm{S}, 145^{\circ} 58^{\prime} \mathrm{E}, 1050 \mathrm{~m}$ a.s.l., 1984, Kantvilas 550/84 (BM, HO); Little Quoin, on vertical dolerite cliff face in eucalypt forest, 1988, Kantvilas 602/88 (HO); Green Head, c. $3 \mathrm{~km}$ SSE of Greystone Bluff, on vertical and overhanging Precambrian metamorphic rocks in alpine moorland, $43^{\circ} 06^{\prime}$ S, $146^{\circ} 04^{\prime} \mathrm{E}, 800 \mathrm{~m}$ a.s.l., 1991, Kantvilas 75/91 (HO, S).

\section{ACKNOWLEDGEMENTS}

We thank Mr B. Fuhrer for use of his photograph and Dr G.N. Stevens for helpful comments on the manuscript.

\section{REFERENCES}

GaLloway, D.J., 1985: FLORA OF NEW ZEALAND LICHENS. Government Printer, Wellington, NZ.

GallowaY, D.J., 1990: Phytogeography of Southern Hemisphere lichens. In Nimis P.C. \& Crovello, T.T. (Eds): QUANTITATIVE APPROACHES TO PHYTOGEOGRAPHY. Kluwer, Dordrecht: 233-262.

Kantvilas, G., 1988: A re-examination of John Shirley's collection of Tasmanian lichens. Pap. Proc. R. Soc. Tasm. 122: 59-67.

Kantvilas, G., 1989: A checklist of Tasmanian lichens. Pap. Proc. R. Soc. Tasm. 123: 67-85.

KANTVIIAS, G. \& JaRMAN, S.J., 1991: Lichens and bryophytes of the Tasmanian World Heritage Area 1. Mount Sprent. In Banks, M.R et al. (Eds): ASPECTS OF TASMANLAN BOTANY - A TRIBUTE TO WINIFRED CURTIS. Royal Society of Tasmania, Hobart: 149-162.

Kantvilas, G., Elix, J.A. \& James, P.W., 1992: Siphulella, a new lichen genus from Southwest Tasmania. Bryologist 95: 186191.

Shirley, J., 1894: Notes on Tasmanian lichens. Pap. Proc. R. Soc. Tasm. (1893): 214-219.

Sipman, H.J.M., 1983: A monograph of the lichen family Megalosporaceae. Bibliotheca Lichenologica 18: 1-241.

Tehler, A., Wright, A.E. \& Galloway, D.J., 1991: Roccellina expectata Tehler, 1 new southern Australian-New Zealand connection. Lichenologist 23: 403-405.

THOR, G., 1990: The lichen genus Chiodecton and five allied genera. Opera Botanica 103: 1-92.

Tibell, L., 1987: Australasian Caliciales. Symb. Bot. Upsal. 27: 1279.

(accepted 6 May 1993) 